\section{UNUSUAL RED-HEADED WOODPECKER RECORD IN MOOSE JAW AREA}

by Rosalind Taylor, Moose Jaw

On July 23, 1963, Mrs. Cy Knight and I went to the farm of Mr. Stan Green, six miles from Moose Jaw, to see a Red-headed Woodpecker (Melanerpes erythrocephalus) which Mr. Frank Brazier had reported to me. He had seen one at this place on July 7 while driving from Boharm to Moose Jaw and later wrote me about it, because I am collecting records of this bird in Saskatchewan.

After checking with Mr. Green at the farm we soon sighted the bird on top of a telephone pole and watched it as it flew down onto the road and then up into the tree tops of the shelter belt on the opposite side of the road. We watched it for scme time, then to our astonishment a second Red-headed Woodpecker appeared and we cibserved the two birds for about an hour.

Several members of the Moose Jaw Natural History Society went out to see the birds and we thought, because the shelter belt contained many old dead trees, we might find a nest or see immature birds. On one of our visits to the farm in late August, we finally found an old dead stump that had had three nests, but whether any of these belonged to the Red-headed Woodpeckers, we do not kncw. We saw no immature birds and Mr. Green did not see the two adult birds after the first week cf August.

In locking over the records (more than 50) which I have collected to date for Saskatchewan, all back to 1900 are for single adult birds. (I have breeding records for 1894 and 1895). That is the reason for our excitement when we sighted the second bird. We shall watch this location closely next spring to see whether the birds return.

(Continued from page 138)

good with Northern Pike, Walleyes, and a few Yellow Perch caught by our pariy. This trip, made by the writers, their son, Alan, and his friend, Gregg Keitn, was of the kind that tne whole party considered very suitable for family groups with fair camping and canoeing skills.

\section{SUMMER OBSERVATION OF WHITE-WINGED CROSSBILLS AT REGINA \\ by Al Binnie, Regina}

A most unusual species of bird, considering the time of year, paid us a visit cn July 15, 1963. Two White-winged Crossbills were observed in our garden at the Provincial Correctional Institution from 8:00 to $8: 15$ p.m. on the abovementioned date. The two birds, one male and one female, were busily cpening aphid-filled galls on the cottonwood trees. We were able to observe closely their great adaptability for this type of feeding. If the number of gall-infested leaves lying on the ground beneath many of the large cottonwoods throughout the grounds was any indication, our crcssbills must have remained in the area several days, although they were not seen again.

A similar cbservation of a related species, the Red Crossbill, feeding on aphid-filled galls on poplar trees in Regina was described by Dr. Gecrge Ledingham in 1959 (Blue Jay, 17:149-150).

\section{INFORMATION WANTED}

Have you seen gulls carrying two black poultry rings on the left leg? In July, 1963, 644 young Glaucouswinged Gulls, part of the Christie Island gull population were banded with US F\&W Service bands on the right leg and poultry rings on the left leg. Information on the success cf the colony and its dispersal movements is wanted. Please report place and number seen for each date of observation and send to Mr. John G. Sarles, The Canadian Wildlife Service, 6660 N.W. Marine Drive, Vancouver, B.C.

\section{CHRISTMAS BIRD COUNT}

Send in reports, listing the numbers of each species seen on the one BEST DAY between December 19 and January 1. In addition, list other species (number of individuals and date seen) between December 19 and January 1.

Send reports as soon as possible to the Editor, Blue Jay, Box 1121, Regina. 